\title{
Narratives of Peace and Progress: Atomic Museums in Japan and New Mexico
}

\section{Alison Fields}

In June 2011, firefighters were struggling to contain the Las Conchas fire, the largest wildfire in New Mexico's history, before it reached the Los Alamos National Laboratory (LANL). Known as the site of the Manhattan Project's secret efforts to develop the atomic bomb during World War II, LANL continues to serve as a major research and development site of nuclear weapons. As the fire threatened the laboratory, attention was focused on Area G, an outdoor facility where thousands of barrels of radioactive waste materials are stored. ${ }^{1}$ While the government sent in planes equipped with radiation monitors and news outlets raised the concern of radioactive smoke, laboratory officials assured the public that this site and other radioactive waste storage was fireproofed and secure.

At the same time, thousands of miles from the high-desert town of Los Alamos, workers at the Fukushima Daiichi nuclear plant in Japan were dealing with the aftermath of an enormous containment failure. A record-breaking 9.0-magnitude earthquake hit off the shore of eastern Japan in March 2011, causing a massive tsunami to crash over seawalls and knock out Fukushima Daiichi's cooling system. The prime minister's office and the Tokyo Electric Power Company worked furiously to prevent a nuclear meltdown but could not prevent a series of explosions at the plant. Reports of radiation unleashed into the environment dealt a major blow to Japan's "safety myth" - a widespread insistence on the infallibility of the country's nuclear power plants. ${ }^{2}$ As the only nation to have been attacked by atomic bombs, Japan's post-World 
War II command of nuclear power was essential in establishing energy independence. Since the recent disaster, Japanese citizens have become increasingly vocal in their anger at the nuclear establishment, drawing on social media to organize mass demonstrations. Mainstream media have largely ignored these protests, and the Japanese government is considering conducting stress tests at all nuclear facilities in the nation to help reassure the public of the safety of nuclear energy. ${ }^{3}$

The efforts for containment at Los Alamos and Fukushima have taken place on two levels: physically, to prevent harm to human bodies and environments, and as a narrative, to reinforce notions of safety, control, and technological progress. But as these unpredictable events of fire, earth, and water demonstrate, beliefs about containment can be instantly overturned, and longsilenced collective memories can resurface to frame new fears. In both New Mexico and Japan, this resurgence of memory occurred as a response to each site's unique nuclear history. Since the development and deployment of the world's first atomic bombs, New Mexico and Japan have served as potent sites of nuclear memories. New Mexico is home to both LANL and the Trinity Site on the White Sands Missile Range, the location of the world's first nuclear test on July 16, 1945. Less than a month later, on August 6, 1945, American forces dropped the world's first atomic bomb on the city of Hiroshima and three days later dropped the second on Nagasaki. The bombs leveled the built environment and killed over 100,000 civilians in Hiroshima and 70,000 in Nagasaki, many almost instantaneously. Radiation poisoning added to these death tolls, and many survivors, or hibakusha, were left with chronic illnesses and disfiguring keloid scars. The bombings were the denouement of World War II in the Pacific and thrust the world into the atomic age.

\section{Trauma and Memory}

The destruction inflicted by the bombing was unprecedented. While citizens of Hiroshima, which had been largely untouched by conventional bombing, had prepared for air raids, the magnitude of the nuclear attack left survivors without words to interpret their experiences. This totalizing event and unknowable experience fits literary critic Shoshana Felman's description of trauma as "the event par excellence, the event as unintelligible, as the pure impact of sheer happening." ${ }^{4}$ In other words, the experience of trauma is so overwhelming that it cannot be understood in the moment it happens. Meaning is assigned only after the event has passed, and even then, it is granted imperfectly, indirectly, and through a series of negotiations. When a collective trauma occurs, negotiations over meaning play a key role redefining and reinforcing group identity and shaping cultural memory. The bombings caused a collective trauma that was remembered very differently in the United States and Japan. Broadly, American memories of the bombings emphasized victory in war and scientific achievement, while Japanese remembrance focused on the loss of lives and 
environments. These memories have been given narrative and visual form at two museums that address the atomic bombings: the Hiroshima Peace Memorial Museum and the Bradbury Science Museum in Los Alamos. This article focuses on these museums as sites where divergent memories are both negotiated and contained.

In the field of trauma studies, many scholars have focused on the challenges and possibilities of articulating trauma through language. However, in Trauma and Visuality in Modernity, Lisa Saltzman and Eric Rosenberg discuss the "visual, or, more specifically, artistic production and practice" in studies of trauma. They argue that trauma's knowability emerges in the "domain that exists between the visual and the verbal, between that which is seen and that which is said." I contend that museums are such domains, merging historical narrative and visual form. The way that trauma is negotiated in a museum setting directly relates to cultural memory. Cultural studies scholar Marita Sturken suggests that cultural memory, which involves the selecting of past events to be linked together in the expression of identity, requires that certain memories be left out or forgotten. The Peace Memorial Museum in Japan and the Bradbury Science Museum in New Mexico fit this paradigm, seeking to interpret and "contain" experiences of trauma in ways that align with accepted cultural memories.

However, my argument is that the experiences of trauma are ongoing, and as the Los Alamos fire and Fukushima radiation leak indicate, the memories they evoke can never be truly settled or contained. A photographic collage by Japanese American artist Patrick Nagatani illustrates this point and provides a useful vantage point for examining the Hiroshima Peace Memorial Museum and the Bradbury Science Museum. ${ }^{6}$ In his 1990 series New Mexico's Nuclear Enchantment, Nagatani's collage titled "Effects of Nuclear Weapons, Bradbury Science Museum, Los Alamos National Laboratory, New Mexico" highlights the complexities of cultural memory ${ }^{7}$ [Figure 1]. The collage's dominant image is a photograph of a museum exhibit that emphasizes the principles of fission, fusion, and radiation. The photograph of the science museum depicts a lofty, industrial feeling interior, reminiscent of a warehouse or factory. Natural light filters in through a steel space frame, revealing a sterile gray floor and oversize navy, orange, and black exhibit panels. No visitors populate the space, and text labels are placed curiously above eye level. The exhibit's central panel is labeled "Weapons Concepts," and the text reads, "A nuclear weapon explosion causes damage through nuclear radiation, intense heat energy, and a powerful blast wave. The specific effects will depend upon the weapon design, explosive yield, location of burst, air surface, or subsurface, and prevailing weather conditions." While the museum text describes how nuclear weapons inflict damage, it is notably silent in listing effects on human bodies.

When Nagatani visited the museum, he was taken aback by the lack of humanity in depicting the toll of nuclear weapons. Reading Peter N. Kirstein's pointed critique of the museum in his article titled "The Atomic Museum" in- 
fluenced him. Kirstein "discusses Bradbury in terms of the psychic denial that stresses the 'friendly,' 'fun,' and 'useful' effects of atomic arsenals." Nagatani was consciously aware at the Bradbury of the lack of danger and dread and felt that the museum's militarize rhetoric resulted in a "psychic numbing" to the mass deaths caused by the bombing. ${ }^{9}$ In his collage, he corrects the absence of trauma by superimposing in the foreground images of several pale, ghost-like Japanese children and a series of glass beakers marked with Japanese names in letters and characters. Nagatani's own nieces and nephews, faces made deathly with gray paint, stand in for the victims of the bombing. While the young ages of the children imply innocence, there ghostly appearances serve as firsthand witnesses to the bombing. The children share their experience through their presence and their direct gaze at the viewer. Nagatani positions the children in the left corner of the collage, their bodies cropped from view and their faces fading into a set of beakers. The beakers, obtained from the University of New Mexico chemistry department and filled with wood ash, reference the bodily remains on display at the Hiroshima Peace Memorial Museum. While both the children and the ashes invoke subjective experience, they are blended with the beakers, becoming instruments of quantifiable scientific measurement. The beakers form a triangle at the bottom of the collage, with the tip pointing back into the exhibit space. Nagatani's collage juxtaposes two very different forms of memory by overlaying the image of the ghostly children and glass beakers onto exhibit panels charting scientific data and, the other, a narrative of human loss contrasting that with technological achievement.

Nagatani's portrait of the children is significant. "Effects of Nuclear Weapons" suggests that such efforts to contain human trauma ultimately fail and that competing memories will continue to haunt the peripheries. Through Nagatani's intervention, a bodily presence is inserted into the aseptic environment of the science museum. In a short film about his series, Nagatani describes his vision to place the ghost children and beakers in the frame of the science museum to "present another display in the museum that they should have." ${ }^{10}$ This insistence that such an alternate display should be part of the science museum raises questions about museum representations of nuclear history. How do the narratives put forth by such museums tell experiences of trauma and with what awareness? Finally, what alternate memories haunt these exhibitions?

\section{The Hiroshima Peace Memorial Museum}

In a speech at the Peace Memorial Ceremony in 1948, Hiroshima Mayor Shinzo Hamai called for "No More Hiroshimas"- a plea that became a motto for the city and for the larger world peace movement. The Peace City Construction law, enacted the same year, guided Hiroshima's postwar construction as the "Peace Memorial City" and the formation of the Peace Park. Hiroshima was marked as a site of a global event, a global trauma, that could not be forgotten. This site also served as a universal symbol with the mission to abolish 
nuclear weapons and enact world peace. The formation of Hiroshima's postwar identity was not politically neutral. Lisa Yoneyama writes that American-led Allied powers "welcomed the proposal to convert the field of atomic ashes into a peace park, while simultaneously enforcing censorship on Japanese publications concerning the bomb's devastating effects on human lives and communities." 11 Japanese leaders also drew on symbols of peace to emphasize the revitalization of the nation's economy after the war, showing the economic growth that emerged from devastation.

In 1955, a memorial museum was developed in Hiroshima to advocate for the abolition of nuclear weapons and to commemorate those who had died in the bombings. Japanese modernist architect Kenzo Tange designed a white, one-story, exposed-concrete museum elevated on forty-foot-tall cement pillars, flanked by two other buildings used for a library and an international conference center [Figure 2]. Tange envisioned the new museum as a "factory of peace" in a newly democratic Japan. ${ }^{12}$ Creating an expansive gateway to the Hiroshima Peace Park, the buildings frame a public square in which up to 50,000 people can gather all around the arched concrete Memorial Cenotaph for Atom Bomb Victims and the Flame of Peace (said to burn constantly until all atomic bombs are destroyed). At the far end of the Peace Park, the shell of the Hiroshima Prefecture Industrial Promotion Hall, now known as the A-bomb dome, stands as the only preserved building in Hiroshima. Tange's Peace Memorial Museum exists as a single piece of a larger memorial landscape, containing over thirty memorials and monuments.

The universal message of peace and nuclear abolition embedded in this memorial landscape serves as the central narrative of the Hiroshima Peace Memorial Museum. Entering the exhibit space, dominated by a three-story reproduction of the A-bomb dome, an introductory video declares the necessity of total nuclear disarmament and world peace, stating, "The possession of nuclear weapons is a threat to the very existence of humanity" and that Hiroshima stands for a "call to unity in the quest for human survival." Critics have charged that this narrative erases the historical context of the bombing, particularly that of Japanese wartime atrocity. In his study of Japanese museums that depict the history of the atomic bomb, lawyer and former Fulbright fellow in Hiroshima Daniel Selz argues that the Peace Memorial Park and Museum has never been a site of debate or inquiry. Selz writes, "The bomb is elevated above history, given such power that it obscures the human choices that led to its use. Commemoration takes precedence over learning in Hiroshima."13 American studies scholar Benedict Giamo also claims that focusing on a universal narrative removes the bomb - and anger at the bomb's destruction - from social reality. Instead, the museum reflects a war "without enemies, historic causes and conditions, motives, end games - without any particulars whatsoever" and in doing so creates a "a national victimology and phantasm of innocence." 14 The critique that the museum presents Japanese citizens as tragic victims, without taking into account Japanese culpability in the war, has persisted. 
However, museum administrators have long struggled to determine what history to include. An early director, Minoru Hataguchi, acknowledged that the museum did not present the early history of the war but argued that since this occurred before the bomb was dropped, it was outside of the museum's scope. He asked, "Do we need to explain everything, even Pearl Harbor? We have to draw the line somewhere." ${ }^{15}$ However, in 1994, Hiroshima's Mayor Takashi Hiraoka observed, "Some of us believe that when we think about the bomb, we should think about the war, too. The world is changing and so perhaps should our view of history." ${ }^{\prime 16}$ As preparations began for the fiftieth anniversary of World War II, the Peace Memorial Museum decided to expand to provide more historical context, creating an exhibit titled "Hiroshima until the Atomic Bombing" on the first floor of the museum's East Building. Just past the opening video, this exhibit space outlines Japan's involvement in World War II and the specific history of Hiroshima as a center for both education and the military. Historic photographs show schoolchildren learning military drills and wearing uniforms, and text panels explain how they were enlisted to plant gardens and demolish wooden buildings that were seen as a liability in the event of a firebombing. Artifacts such as propaganda posters and commodity forms were shown, emphasizing the totalizing impact of the war. Japan's own participation in wartime aggression, such the attack on Pearl Harbor and the capture of Nanjing, are presented in broad strokes problematically. Other key events, such as the Bataan Death March, are left out entirely, even though the museum attempted to address its critics.

Moving counterclockwise through the exhibit space, the historical time line is interrupted by a floor-to-ceiling image of a clock frozen at 8:15, the moment of the bombing. The accompanying text gives this narrative account: "A dragonfly flitted in front of me and stopped on a fence. I stood up, took my cap in my hands and was about to catch the dragonfly when ..." A watch stopped at $8: 15$ is encased in front of the image, emphasizing the distortion of time caused by the bombing. The visual and narrative disruption to the time line reinforces the notion that the bombing was a sudden, all-consuming event that stood outside of time. Next, a three-part exhibit sets out to explain why the United States developed the bomb, decided to use it, and picked Hiroshima as its first target. The panels suggest that President Truman's choice to use the bomb reflected the need for the United States both to gain a strategic advantage over the Soviet Union and to justify the expense of the $\$ 2$ billion, top-secret Manhattan Project to the American public.

Following this display, an enlarged photograph titled "Hiroshima in Ruins" showed the city two months after the bombing. An adjacent wall shows letters submitted in protest by Hiroshima mayors over each and every nuclear test conducted after Hiroshima. Next, visitors are directed to the center of the room to view two circular models - one of Hiroshima just before bombing and one afterward. Television screens semienclose this interior space, with images and testimony from the morning of the bombing. Underneath, an enlarged photo- 
graph from the morning of the bombing shows survivors huddling around an aid station, one of only two photographs taken by a photojournalist that day. After viewing the materials on the first floor, visitors go upstairs to see an exhibit space dedicated to environmental and medical recovery after the bombing and then on to a presentation about ensuing arms races. Another short set of stairs leads to an open area with a long gift shop counter, ending the narrative flow of the first set of exhibits.

Moving on from the newer exhibit spaces, visitors must cross a long skywalk to the original museum building, where they are immediately confronted with nine enlarged images of the mushroom cloud. After these images, the visitor walks down a darkened hallway, reconstructed as a dilapidated brick building. At the end of the hallway, the museum's only diorama appears, in dark shadows and dim red lights. Three life-size models of children, with bloodied, swollen faces and arms and tattered clothing, are shown as if in motion, making their way through a ruined landscape. A sign nearby describes the moment of the bombing: "All of the buildings within two kilometers of the hypocenter were crushed to rubble and burned. Intense thermal rays charred the clothes people wore. Covered in blood, clothes in tatters, those who were able to fled their devastated city." When moving into this gallery space, guided tours of the museum also showed a notable shift in tone.

This change in tone demands a more emotional, connected response, bringing the visitor closer to the reality of that day. Personal artifacts, displayed one after the next, tell individual stories of those who died in the bombing. On the day of the bombing, many of the children who were impacted were wearing similar uniforms and were badly burned so that it became impossible to tell them apart. Small personal artifacts and signifiers - a cap with a name on it, a lunchbox with carbonized remains, and a water bottle with the family namebecame ways to identify the otherwise nameless dead. For those listening to the audio tour, the narrative sharply changes here. Instead of hearing facts about Hiroshima's history and destruction, a series of personal stories takes over. Each story provides the victim's name, their proximity to the hypocenter, and the names of those who tried to find them. The stories align with the artifacts on display - a mother sending her child off to school with a special lunch and parents watching their three-year-old ride a tricycle when the bomb hit. Narratives are built around these artifacts in such a way that they stand in for the person they belonged to. One after the next, personal stories are repeated to devastating effect - mimicking the melancholic feedback loop of trauma.

In a tour with a museum volunteer, the guide shifts her narrative to personal stories at this moment, too-she tells of a coworker who was biking with her little brother on her back when the bomb hit. Her brother died but shielded her from injury. Another display prompts the volunteer to discuss the death of her mother, who died due to a lack of available treatment and her own reluctance to seek care after flying shards of glass were embedded in her body. This museum guide was one of approximately thirty survivor-storytellers who engage in edu- 
cational tours and programs at the museums. As these survivors age, efforts are being made to digitize their stories. ${ }^{17}$ Overall, this exhibit space and interpretive accompaniment reinforces the difficulty of children separated from their parents and the trauma that surviving children faced in losing their families.

Next, visitors move to an exhibit area dealing with the impact of extreme heat. The major visual focal points in this room are of building materials impacted by the heat. We see twisted-in iron shutters and pushed-up and raised rooftops. One of the museum's most well known artifacts is shown here-a shadow burned on the wall and steps of the Sumitomo Bank. Along with the building materials, several enlarged photographs graphically show the burns on human bodies. The focus quickly returns to material objects, however, as the fire that broke out after the bombing melted and contorted objects in a way that looks almost volcanic. Fine china, teacups, and burnt Buddha figures illustrate this damage. The last major exhibit area deals specifically with the impact of radiation. On the walls, text panels explain the production of black rain, and an exposed wall marked with black streaks stands as a testament. Human effects of radiation are shown next. In addition to images of the purple spots caused by radiation, actual body parts - human hair, a diseased tongue, and surgically removed keloids - are on display. The bodily remains on display refer to a kind of trauma that is unique, and it is challenging for viewers to process these items. In a final exhibit, this trauma is personalized through a time line that tells the life story of Sadako Sasaki, whose exposure to radiation as an infant resulted in her death of leukemia at age eleven. Through the end of her life, she believed she would recover because she was in the process of folding 1,000 origami cranes for good luck. When she died in 1955, her classmates folded the remaining 356 to be buried with her and helped to fund the Children's Peace Monument. Visitors to the park continue to bring paper cranes in honor of Sadako.

The entirety of the original museum space, with its displays of personal artifacts, structural remnants, and bodily remains, addresses a core challenge of memorial museums: that "acts of physical violence are ephemeral" and cannot be easily captured on museum walls. ${ }^{18}$ When mass trauma is inflicted, the intent is to destroy human bodies and physical environments, leaving little left to tell the story of what occurred. How can museums show what is no longer? The human shadow burned on the wall and steps of the bank offers one answer to this question. Like Nagatani's ghostly children and ash-filled beakers, this artifact offers the trace of what was once there. Through "Effects of Nuclear Weapons," Nagatani imaginatively represents bodies that are no longer present and that became dust in the instant of the bombing.

The opening scenes of the 1959 film Hiroshima Mon Amour grapples with the nature of seeing and influenced Nagatani's representation of bodily absence. As the film begins, a French woman named Elle and a Japanese man named Lui lie tangled in bed and speak of their experiences and knowledge of the bombing in Hiroshima. While the fictional Elle is not a firsthand witness of the bombing, based on her visit to the museum, she claims that she "knows" what happened. 
Elle recounts, "Four times at the museum in Hiroshima, I watched the people. I myself, lost in thought, looked at the scorched metal, the twisted metal, metal made as vulnerable as flesh. I saw the bouquet of bottle caps. Who would have thought? Human flesh suspended, as if still alive, its agony still fresh." ${ }^{\prime 9}$ As Elle moves through the museum in the film, physical structures and bodily remains seem to exist on a continuum, with damage to material objects echoing damage to human flesh. In the present-day museum, the emphasis placed on both physical destruction and bodily suffering highlight experiences of human loss.

After learning Sadako's story, a return table for the audio guides marks the official end of the exhibit space. To exit, however, one passes through a hallway of video booths playing survivor testimony, with a glass wall facing the Peace Park, again joining the museum to the outside memorial spaces. While the newer exhibit spaces ask visitors to consider the larger historical context of World War II, the intimate personal artifacts and narratives presented by the museum highlight its function as a memorial to human loss. In recent years, the museum has undergone a review process, and a proposal put forward in 2007 recommends the addition of another entryway to allow visitors a choice in which part of the museum they wish to view. Additional space for meditation at the end of the exhibits was also recommended. ${ }^{20}$ The museum draws over 1.5 million visitors each year, including many schoolchildren who come to focus on the museum's message of peace. The message of peace becomes a mode of containment for the graphic and upsetting images of human trauma.

\section{The Bradbury Science Museum}

Nagatani's collage suggests that even when left out of public remembrance, the presence of atomic victims cannot be fully erased and continue to haunt narratives of scientific technology. However, at the Bradbury Museum in Los Alamos, New Mexico, there is little to suggest the human toll caused by the bombs [Figure 3]. Rather, the museum focuses on the scientific ingenuity of creating the first atomic bomb, the progress made in nuclear research, and the importance of securing and defending the nation. The museum's stated mission is as follows:

The Bradbury Science Museum's primary mission is to interpret Laboratory research, activities, and history to official visitors, the general public, and Laboratory employees; to promote greater public understanding of the Laboratory's role in national security programs; to assist the taxpaying public in making informed judgments in these matters; and to contribute to visitors' knowledge of science and technology and to improve the quality of math and science education in northern New Mexico. ${ }^{21}$ 
New Mexico, the birthplace of the nuclear weapons industry, remains today a site of research, manufacturing, and refining of active uranium mines and of radioactively contaminated land. The Bradbury Science Museum, founded in 1962 and moved to its current location in 1993, is located in the center of the remote, high-desert town of Los Alamos and bills itself as a bridge between LANL and the community. ${ }^{22}$

Atomic museums in the United States are placed near sites of nuclear weapons production, "spaces [that] are alternately secured, monitored, contaminated, and forbidding." Bryan C. Taylor suggests that museums situated near such production facilities boast an authenticity of place but also "invite visitor unease about uncontrolled contact with both ominous symbolism and residual radiations from weapons production operations. ${ }^{.23}$ Unstable boundaries between nuclear objects on museum display (presumed to be at a safe remove) and those in use in nearby facilities heighten this feeling of unease. While a formal extension of LANL, the low, gray and orange stucco building of the Bradbury Museum blends in with its unremarkable commercial surroundings. Unlike many of LANL's buildings, the science museum requires no special clearances and is free and easily accessible to the public.

The Bradbury Museum draws about 100,000 visitors per year, reaching a far smaller audience than the museum in Hiroshima. On entering the main lobby, the museum's exhibit space is clearly divided into three galleries - the History Gallery, the Research Gallery, and the Defense Gallery - each with a separate entrance. Visitors typically start in the History Gallery, where the background of the laboratory is depicted in linear fashion. This gallery provides illustrated time lines, newspaper clippings announcing major world events, documentation, and video of life in Los Alamos as the site of a boys' ranch school transformed into a laboratory for harnessing nuclear power. Entering the gallery and moving from left to right, the exhibit begins with a text panel addressing the beginning of the atomic age. Noting the research developments in understanding atomic fission and the start of World War II, "Scientific curiosity turned into realization that a weapon of incredible power was possible." According to a quote by French scientist Bertrand Goldschmidt, this power quickly became the domain of "a new elite ... nuclear scientists aware of their moral and political responsibilities" in shaping history. A curving time line covering scientific developments in atomic physics from 1895 to 1945 illustrates this trajectory.

Two other time lines are prominent in exhibit space. The first, depicting major world events, runs along the top of the left wall, ticking off the years between 1932 ("Prelude to War") and 1945 ("War in the Pacific"). A second, smaller time line positioned lower in the exhibit demarcates key events in the laboratory's history. The area between the time lines is covered in a collage-like fashion with text, historic photographs of Los Alamos, American newspapers from the beginning of World War II, and television screens looping a short video about the Manhattan Project. Small tables and stools against the exhibit wall allow visitors to view the videos and push large red buttons to hear further 
narratives from the scientists involved. Detailed white statues of Robert Oppenheimer and Lieutenant General Leslie Groves, key players of the Manhattan Project, stand prominently on either side of one of the stools. Groves is adorned in rumpled military dress and scowls in the distance, while Oppenheimer is nattily dressed in a suit, tie, and top hat and seems to be engaging him in conversation. Sitting in the midst of this overflow of visual, textual, and aural information, contained between two time lines and two towering figures in atomic history, immerses viewers and places them squarely inside the historical narrative presented in the exhibit. Moving around the room, the far wall of the exhibit focuses on the early 1960s, again including a time line and news clippings pertaining to the Cold War. The last wall is dedicated to framed black-and-white photographs and biographies of "The People of Project Y at Los Alamos, 19431945" under the heading "They Changed the World." A short film, titled "The Town That Never Was," plays on a loop in an adjacent auditorium, recounting the early history of Los Alamos and its transformation during the war.

Visitors would likely move next to the Research Gallery, where the range of research conducted at the lab is highlighted, including projects in computing, radiation, lasers, accelerators, and space science. This dimly lit gallery offers several interactive activities but is mostly an informational space, with steelframed panels featuring text and diagrams on environmental and medical topics. Brain mapping, understanding the human genome, global climate research, and scientific computing are among the highlighted points. A instructional room called the "Tech Lab" is accessible through this gallery, as is the museum's second short film, "Mission: Stockpile Stewardship." The film stresses the importance of maintaining reliable nuclear weapons that could serve as a deterrent from attack. This message segues directly into the Defense Gallery, the exhibit space reflecting the main mission of the laboratory, that of national security. The exhibit includes reproductions of a "W80 warhead, air-launched cruise missile, Mark 12A, B61 and B83 bombs, and Fat Man, a bomb identical to the one dropped on Nagasaki and similar to the device tested at Trinity." The gallery also includes information about the Nevada test site and underground testing.

While, again, the stated purpose of the museum is to represent the "research, activities, and history" of the laboratory, there is only one space made available for antinuclear narratives. A small alcove between the Research and Defense galleries is used to acknowledge the debate over using the bomb-a public comment book is available, as is wall space for non-laboratory-related groups to post their positions. This tucked-away corner shows how competing narratives have been pushed to edges of the museum but are necessarily present. The three tiers reflect the way LANL envisions itself, suggesting the scientific progress made over the decades and the need for nuclear defense. This narrative is also employed by other atomic museums in the United States. In a review of the Atomic Testing Museum in Las Vegas, Nevada, Matt Wray notes that in this museum "there was, to my eye, no visible critique of the foundational tenets of scientism - the ideological belief that superior technology 
liberates us and serves as a the guarantor of freedom and democracy." Alternative narratives appear only as "blips on the lengthy timeline that snakes across the walls, brief snippets of video in multimedia presentations. ${ }^{.24}$ Like at the Bradbury Museum, conflicting narratives of human trauma are minimized or left out entirely.

The gift shop at the Bradbury Museum is in a neighboring building and sells a wide range of toys, books, and souvenirs. The gift shop creates an end point for the museum self-tour and provides the opportunity to take home a visual reminder. The gift shop completes the museum's neat story and contains the visitor's experience. By purchasing a souvenir such as a shot glass decorated with a metal replica of Fat Man and Little Boy or a faux road sign reading "Atomic Avenue," attention is shifted away from any troubling thoughts of American aggression. In Sturken's examination of tourist practices after the Oklahoma City bombing and 9/11, she discusses the complex relationship between traumatic memory, consumerism, security, and kitsch. Kitsch objects signify the "complex relationship of mourning and consumerism and the economic networks that emerge around historical events." ${ }^{25}$ The atomic bombing influenced some of the most broadly recognizable kitsch objects in America. In particular, A. Costandina Titus writes, the mushroom cloud itself has become an excellent example of American kitsch and, "ironically, is viewed somewhat wistfully as a nostalgic icon evocative of a simpler, safer times. ${ }^{26}$ As a symbol of American power and military achievement, the circulation of mushroom cloud imagery reinforces national narratives of scientific progress and defense. Through the kitsch objects available for sale at the Bradbury Museum's gift shop, the human trauma caused by the bombing is evaded, and the "friendly" and "fun" aspects of nuclear power noted by Kirstein are emphasized.

\section{Museums and Memory}

In addition to juxtaposing differing narratives of nuclear history, Nagatani's Nuclear Enchantment series poses the museum as a site for learning and conveying cultural memory. No longer simply the treasure chests of the elite, museums serve many different functions and cater to diverse audiences. Curators, administrators, and donors, among others, all play a role in shaping museum narratives in accordance with mission statements and the expectations of the anticipated audience. As anthropologist Sally Price notes, "While every telling of a tale is an act of construction, with some details put in and others left out, museum media demand a particularly merciless level of selectivity, and that gives them special power to slant stories in one direction or another." ${ }^{27}$ These choices have lasting implications on how traumatic events are represented and remembered over time and made nostalgic. Much has been written about the controversies inherent in representing the atomic bomb to a broad audience, particularly after the Enola Gay exhibition at the National Air and Space Museum faced numerous revisions in the 1990s. ${ }^{28}$ Museum spaces, with 
their combination of narrative discourse and visual representation, are crucial to shaping narratives that make trauma knowable. However, in framing experiences of trauma, museums necessarily privilege certain memories and push others to the periphery.

Overall, the Hiroshima Peace Memorial Museum and the Bradbury Science Museum employ similar conventions of museology —using historic photographs, artifacts, text panels, time lines, dioramas, and model replicas to contain and distill national narratives about atomic power. In constructing narratives of atomic history in Japan and New Mexico, both museums influence how this history will be passed down to future generations. When considering how the two sites pass on particular memories of atomic trauma, however, the purpose of each type of museum must be addressed. Paul Williams explains that memorial museums are "dedicated to a historic event commemorating mass suffering of some kind," while science museums seek to develop understanding of the natural world. ${ }^{29}$ Therefore, the memorial museum centers on a specific moment in time, while the science museum takes a longer view of the past. As a result, the two types of museums reach very different audiences and inspire divergent forms of cultural memory.

The Hiroshima Peace Museum provided a model that many later memorial museums followed. It represents a past "widely considered as settled," where human suffering is offered up as a sacrifice needed to reach the abolition of nuclear weapons and world peace..$^{30}$ The museum's narrative does not dwell on guilt or blame but instead relies on objects and images to evoke empathy. In contrast, the Bradbury Science Museum is not tethered to the event of the bombing but rather seeks to paint a broader picture of the long-term development and possibilities of nuclear power. While Hiroshima turns to the message of peace to address human loss and provide closure for trauma, Los Alamos seeks to maintain a program of nuclear research in line with American notions of technological ingenuity, homeland security, and scientific progress.

However, as recent radiation scares indicate, narratives that seek to contain atomic trauma are always precarious and incomplete. Long-established cultural memories, presented in museum as "settled," may be quickly overturned by the likes of a tsunami. As we have seen, Nagatani's "Effects of Nuclear Weapons" provides a visual representation of the lack of easy resolution to atomic trauma. In the specter of the ghostly children, the promise of trauma - the total disruption of safety that would take young lives - haunts the exhibit space of the science museum. This ghostly haunting forces viewers to consider how including the personal remains of bombing victims, such as those on display in Hiroshima, might complicate existing atomic science museums and stories. Finally, by looking closely at the exhibit spaces themselves, spaces for alternative memories can be located. Both the Hiroshima Peace Memorial Museum and the Bradbury Science Museum offer evidence that experience of atomic trauma cannot be fully contained. 


\section{Notes}

1. "Firefighters Scramble to Protect Nuclear Facility," MSNBC, http://www.msnbc.msn. com/id/43558540/ns/weather/t/firefighters-scramble-protect-nuclear-facility, June 29, 2011.

2. Norimitsu Onishi and Kantaro Suzuki (contributed reporting), "'Safety Myth' Left Japan Ripe for Nuclear Crisis," New York Times, June 25, 2011.

3. Mitsuru Obe, "Japan Ponders Wider Nuclear Tests," Wall Street Journal Asia, http://online.wsj.com/article/SB10001424052702303544604576429560834436354.html, accessed July 1, 2011.

4. Lisa Saltzman and Eric Rosenberg, "Introduction," in Trauma and Visuality in Modernity (Hanover, NH: Dartmouth College Press, 2006), xi.

5. Ibid., xii.

6. Nagatani's artwork has been featured in thousands of group and solo exhibitions worldwide. He has received awards from the Ford Foundation and the National Endowment for the Arts, among many other fellowships and grants. He is a professor emerita at the University of New Mexico.

7. Eugenia Parry Janis and Patrick Nagatani, New Mexico's Nuclear Enchantment (Albuquerque: University of New Mexico Press, 1991).

8. Ibid.

9. By using this label, Nagatani recalls Robert Jay Lifton's study Death in Life: Survivors of Hiroshima (Durham: University of North Carolina Press, 1991), 31.

10. New Mexico's Nuclear Enchantment, http://portal.knme.org/video/1476806820, accessed March 1, 2013.

11. Quoted in Paul Williams, Memorial Museums: The Global Rush to Commemorate Atrocities (New York: Berg, 2007), 136.

12. Yushi Utaka, "The Hiroshima 'Peace Memorial': Transforming Legacy, Memories, and Landscapes," in Places of Pain and Shame: Dealing with "Difficult Heritage," ed. William Logan and Keir Reeves (New York: Routledge, 2009), 37.

13. Daniel Walkowitz and Lisa Maya Knauer, Memory and the Impact of Political Transformation in Public Space (Durham, NC: Duke University Press, 2004), 135.

14. Benedict Giamo, "The Myth of the Vanquished: The Hiroshima Peace Memorial Museum," American Quarterly 55, no. 4 (December 2003):714.

15. Quoted in Martin Fackler, "Hiroshima and the Meaning of Victimhood," New York Times, August 6, 2005.

16. Quoted in David Sanger, "Hiroshima Journal; Museum's A-Bomb Message: There's More to It," New York Times, August 4, 1994.

17. Utaka, "The Hiroshima 'Peace Memorial,", 44.

18. Paul Williams, Memorial Museums: The Global Rush to Commemorate Atrocities (London: Berg, 2008), 33.

19. Hiroshima Mon Amour, 1959.

20. Utaka, "The Hiroshima 'Peace Memorial," 44.

21. See http://www.lanl.gov/museum.

22. See ibid.

23. Brian C. Taylor, "Radioactive History: Rhetoric, Memory, and Place in the Post-Cold War Nuclear Museum," in Places of Public Memory: The Rhetoric of Museums and Memorials, ed. Greg Dickinson, Carole Blaire, and Brian L. Ott (Tuscaloosa: University of Alabama Press, 2010).

24. Matt Wray, "A Blast from the Past: Preserving and Interpreting the Atomic Age," American Quarterly 58, no. 2 (2006): 473-74.

25. Marita Sturken, Tourists of History: Memory, Kitsch, and Consumerism from Oklahoma City to Ground Zero (Durham, NC: Duke University Press, 2007), 4.

26. A. Costandina Titus, "The Mushroom Cloud as Kitsch," in Atomic Culture: How We Learned to Stop Worrying and Love the Bomb, ed. Scott C. Zeman and Michael A. Armundson (Boulder: University of Colorado Press, 2004), 102.

27. Sally Price, Paris Primitive: Jacques Chirac's Museum on the Quai Branly (Chicago: University of Chicago Press, 2007).

28. See Steven C. Dubin, Displays of Power: Controversy in the American Museum from the Enola Gay to Sensation (New York: New York University Press, 1999), and Edward T. Linethal, History Wars: The Enola Gay and Other Battles for the American Past (New York: Metropolitan/ Holt Paperbacks, 1996).

29. Williams, Memorial Museums (XXXX), 7.

30. Ibid., 121. 